\title{
Effects of Pollination Interventions, Plant Age and Source on Hormonal Patterns and Fruit Set of Date Palm (Phoenix dactylifera L.)
}

\author{
Hassan Ali-Dinar ${ }^{1, *}$, Maged Mohammed ${ }^{1,2, *}$ (D) and Muhammad Munir ${ }^{1}$ (D) \\ 1 Date Palm Research Center of Excellence, King Faisal University, Al-Ahsa, Hofuf 31982, Saudi Arabia; \\ mmunir@kfu.edu.sa \\ 2 Agricultural Engineering Department, Faculty of Agriculture, Menoufia University, \\ Shebin El Koum 32514, Egypt \\ * Correspondence: hdinar@kfu.edu.sa (H.A.-D.); memohammed@kfu.edu.sa (M.M.)
}

\section{check for}

updates

Citation: Ali-Dinar, H.; Mohammed, M.; Munir, M. Effects of Pollination Interventions, Plant Age and Source on Hormonal Patterns and Fruit Set of Date Palm (Phoenix dactylifera L.). Horticulturae 2021, 7, 427. https:/ / doi.org/10.3390/horticulturae7110427

Received: 12 September 2021

Accepted: 20 October 2021

Published: 22 October 2021

Publisher's Note: MDPI stays neutral with regard to jurisdictional claims in published maps and institutional affiliations.

Copyright: (c) 2021 by the authors. Licensee MDPI, Basel, Switzerland. This article is an open access article distributed under the terms and conditions of the Creative Commons Attribution (CC BY) license (https:// creativecommons.org/licenses/by/ $4.0 /)$.

\begin{abstract}
Date palm is widely propagated through conventional offshoots. It is also produced through a tissue culture technique due to the limited number of offshoots produced throughout the course of a palm's life. Being dioecious, it is a cross-pollinated tree that can be naturally or artificially pollinated. Tissue-cultured plants often have abnormal epigenetic or genetic changes that affect specific phenotypic characteristics. The growth of parthenocarpic fruits in date palms is mostly induced by hormonal imbalances in certain tissues. The major hormones in parthenocarpic fruits are auxins (IAA), gibberellins $\left(\mathrm{GA}_{3}\right)$, and abscisic acid (ABA). Parthenocarpic, or abnormal fruit development, is an undesirable trait for date palm growers since it drastically reduces farm income. The current study was therefore conducted over two seasons to confirm previous observations and included conventional offshoot-derived trees (CO) and tissue culture-derived ones (TC) of the cultivar Barhee. According to the observed ratio of the fruiting abnormalities, two date palm tree ages were selected, i.e., 6 and 13 years. Two pollination interventions were used: pollination of naturally open female spathes (NOP) and pollination of forced open female spathes (FOP). Plant hormones, IAA, $\mathrm{GA}_{3}$, and $\mathrm{ABA}$ were identified just before pollination and at specific intervals after pollination for up to 85 days. The ratio of the abnormal fruit set was identified 5 days after pollination. Significant differences were observed in hormonal levels between tree ages as well as between tree propagation sources. Young TC trees (6-year-old) had high abnormal fruit sets compared to CO date palm trees that were the same age. During the early fruit growth and development phases, CO date palms had much higher amounts of IAA and $\mathrm{GA}_{3}$ than TC date palms. However, ABA concentrations were surprisingly higher in the TC trees during the early fruit growth stages, while it immediately decreased after pollination in the $\mathrm{CO}$ date palms. The ratio of abnormal fruits was significantly reduced in the 13-year-old TC date palms, and no differences were observed compared to the $\mathrm{CO}$ ones. The levels of IAA, $\mathrm{GA}_{3}$, and ABA hormones in both young and old date palms derived through $\mathrm{CO}$ or TC followed similar patterns. The critical observations regarding the ABA pattern in the old TC date palms (13-year-old) gradually dropped after pollination, which was identical to the CO ones, whereas it was the opposite in the young 6-year-old TC date palm plants.
\end{abstract}

Keywords: date palm; plant hormones; indole acetic acid; gibberellins; abscisic acid; parthenocarpic fruits; natural and forced pollination; palm age

\section{Introduction}

The date palm (Phoenix dactylifera L.) is grown in arid and semi-arid climates with hot summers and frost-free moderate winters. Globally, it is cultivated on $1.40 \mathrm{Mha}$, with an annual production of $9.23 \mathrm{MT}$ [1]. It is a cross-pollinated fruit tree due to its dioecious nature, with pollen grains applied to female inflorescence [2]. The male and female flowers are arranged unsystematically on a spikelet enclosed in a hard sheath, 
collectively called a spathe. The female date palm flower is comprised of three carpels and only one carpel develops into a fruit after pollination, while the rest disintegrate. However, due to inefficient pollination practices, triple parthenocarpic fruits with all three non-fertilized carpels are formed [3]. The timing with which the spathes emerge and the opening of both flowers are different. The male spathes emerge earlier than the female ones, making cross-pollination inevitable [4]. When pollen grains settle on the stigma of females, they begin to germinate a pollen tube guided by several female-secreted peptides, allowing the pollen to enter into the female ovary for fertilization $[5,6]$. The efficiency of pollination and the fruit set depends on several factors such as male flowering time, pollinizer source, the viability and amount of pollen grains, pollination time, and the receptivity of female flowers [7-10]. However, the best pollination results can be observed within 2-4 days of pollination if these factors are ideal [4,9]. The date fruit goes through several developmental stages after fruit setting, including Hababouk, Kimri, Khalal (Bisr), Rutab, and Tamr (Figure 1). The length of these phases varies with the cultivar $[4,11,12]$.

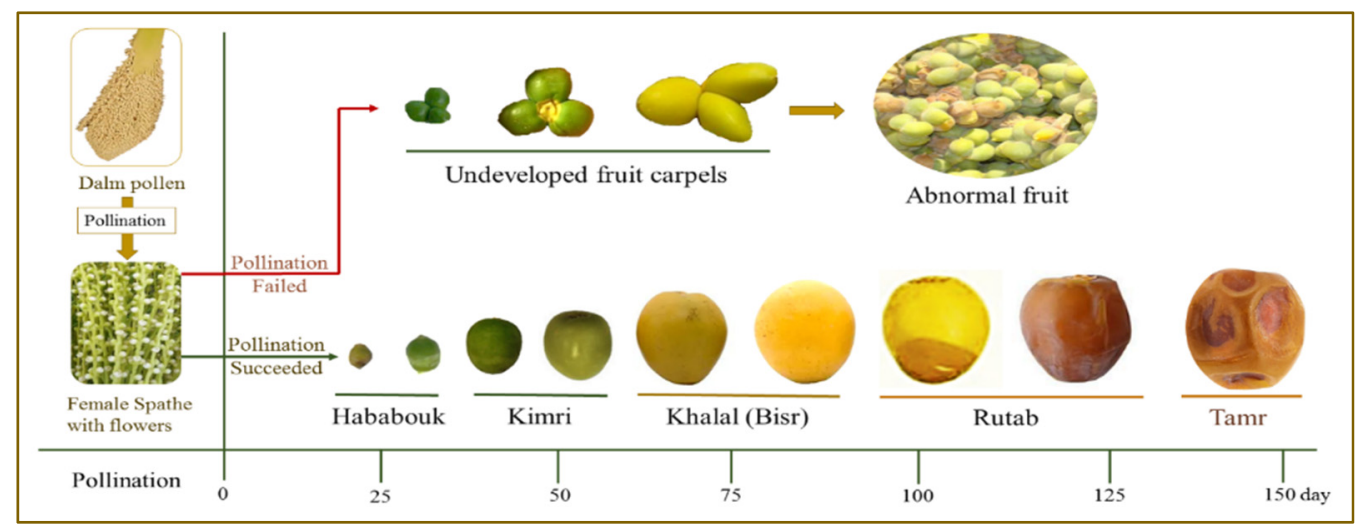

Figure 1. Development stages of date palm fruit after pollination.

The date palm is pollinated naturally by the wind or by insects, but this approach has proven inefficient and results in a considerably lower yield because male flowers normally open well before the female flowers [13,14]. Furthermore, even with the presence of male pollinizers with viable pollen grains in close vicinity to the female palms, this will not ensure effective pollination due to the lack of insect attractance. In general, the pollination of $60-80 \%$ of the female flowers is considered adequate for good fruit set and yield [15]. Pollination efficiency is also influenced by a number of parameters, including pollinizers, pollination time and methods, male flowering time, pollen viability, pollen quantity and quality, and the responsiveness of female flowers $[9,15,16]$. Therefore, artificial or forced pollination is widely used in commercial date palm plantations to improve crop yield and quality [17]. A variety of artificial date palm pollination methods have been used to achieve optimal fruit set and yield benefits, including male strand placement (hand pollination), manual and mechanical pollen dusting, and pollen suspension methods [9,18]. Adopting a more appropriate and enhanced pollination method could save labor costs, increase pollen grain quantity, and increase fruit yield [19].

Date palm is commonly propagated through conventional vegetative offshoots. However, due to the limited number of offshoots produced over the course of a palm's life, the risk of disease and pest spread, and the minimum plant survival rate, it is unable to meet demands for commercial date palm cultivar offshoots [4]. Consequently, commercial cultivars are raised in vitro under a controlled environment for rapid mass propagation and are genetically uniform and disease-free [20,21]. In vitro produced plants, on the other hand, exhibit epigenetic or genetic changes that have been observed in a variety of plant species, including date palm. These variations negatively alter certain phenotypic traits compared to their mother plant [22,23]. These abnormal changes include excessive vegetative growth, delays in flowering time, floral fertilization failure, parthenocarpic fruit formation, dwarfism, leaf variegation, leaf discoloration, production of aerial offshoots, 
and increased vulnerability to diseases [24-26]. Floral fertilization failure is the most economically damaging issue of these abnormalities. This anomaly has a major impact on productivity and crop yield as well as the overall economics of the cultivation process. Several tissues from culture-derived date palm trees in Saudi Arabia had low levels of fruit set and extra carpels $[27,28]$. Parthenocarpic fruits with more than three carpels were found in 80-100 percent pollinated bunches from tissue-cultured plants. The use of somatic embryogenesis was found to be the critical cause of irregular fruiting. It was observed that more than $57 \%$ of tissue-cultured date palm cv. Barhee trees had abnormal fruit sets. This poor fruit set phenotype was linked to structural abnormalities in the flowers, including the absence of an ovule $[29,30]$. In tissue culture-derived date palms, abnormalities such as aberrant fruit set, size, and shape were observed to be caused by changes in DNA methylation patterns [31,32].

Studies on reproductive development concerning the environment, genetic, and biochemical factors in date palm and other fruit crops have increased over the past few years [33-36]. Several events such as cell division and the differentiation and expansion of tissues are involved during fruit development after pollination. Fruit growth either fails or is significantly restricted in the absence of floral fertilization [37], which most likely due to insufficient endogenous hormone regulation $[36,38]$. Hormones produced inside of the ovule resulting from floral fertilization play a vital role in fruit development and ripening processes in higher plants [35,39-41]. Auxins, gibberellins (GAs), cytokinins, abscisic acid (ABA), and ethylene are plant hormones that regulate growth and development during various stages of fruit development [42,43]. Furthermore, the effects of growth regulators such as jasmonic acid, salicylic acid, polyamines, and brassinosteroids on fruit development and ripening have also been reported [44,45]. Attempts have also been made to identify the expression of genes involved in hormone regulation during the development and ripening of fruits $[46,47]$. In previous studies regarding fruit set in plants, different concentrations of IAA, $\mathrm{GA}_{3}$, and $\mathrm{ABA}$ were observed during the first stages of fruit growth and development (flowering, pollination, pollen tube growth, fertilization, etc.) [42,48-50]. IAA and $\mathrm{GA}_{3}$ interaction normally promote fruit growth and development, while the ABA role is more dominant during fruit ripening and senescence [45]. Moreover, it has been observed that interaction between the auxin and GA signaling pathways is required for fruit set promotion in fleshy fruits $[48,51,52]$. The SIARF7 gene acts as a modifier of both auxin and gibberellins during fruit set and development in tomatoes. It modulates a part of the auxin signalling pathway when it is upregulated, but when it is downregulated, it affects the GA signalling pathway, which is important in fruit set and development [48,51]. The combined activity of plant hormones including auxin, GA, and cytokinin also plays a key role in fruit set regulation [53]. Evidence suggests that auxin enhances fruit set and development, which is partially caused by modulating the GA levels [54,55]. In another study, Al-Kalifah et al. [56] found that applying kinetin exogenously before pollination lowers the parthenocarpic fruit in tissue culture-derived date palms. The upregulation of the ethylene hormone has been found to trigger and enhance fruit ripening processes in date palms [57-59].

Many scientists have been interested in the abnormal fruit development of tissue culture-derived date palms, particularly the cultivar Barhee, in recent years [49,50]. Attaha and al-Saadi [60], in their anatomical and hormonal studies in date palm fruit set, revealed many structural deformities in the flower parts in abnormal fruits. These deformities included the separation of the style from the stigma and ovary, the disintegration of the ovules, and the absence of zygotes. During the early events of fruit growth, all of those phenomena occurring following pollination resulted in an abnormal fruit set. Studies to elucidate the probable causes of this phenomenon mainly concentrated on the anatomical and hormonal levels of the affected tissue culture trees. According to our knowledge, none of the previous studies have comprehensively included vital factors such as pollination techniques, date palm tree age, and propagation sources to identify the possible causes of this abnormality in the fruit set. These findings support the hypothesis that hormones play 
a role in date palm parthenocarpic fruit development. On the other hand, the hormone profiles of developing date palm fruits of $\mathrm{cv}$. Barhee have yet to be determined, and the cause of parthenocarpic fruit remains unexplained. The present study aims to appraise the role of plant hormones in the development of parthenocarpic fruits in an in vitro derived offshoots by tracking hormonal activity during the production of the date palm fruit of cv. Barhee.

\section{Materials and Methods}

\subsection{Experimental Site}

The experiment was conducted at Date Palm Research Center of Excellence, Training and Research Station, King Faisal University, Al-Ahsa, Kingdom of Saudi Arabia (Latitude $25^{\circ} 16^{\prime} 24.4524^{\prime \prime} \mathrm{N}$, Longitude $49^{\circ} 42^{\prime} 28.5948^{\prime \prime}$ E, and Altitude $155 \mathrm{~m}$ above sea level) during 2018 and 2019. The soil of the experimental orchard (1) sandy loam texture (65\% sand, $22 \%$ silt, and $13 \%$ clay), (2) a soil field capacity of $14.8 \%$, (3) a permanent wilting point 5.2 , (4) a bulk density $1.55 \mathrm{~kg} \cdot \mathrm{m}^{-3}$, (5) electrical conductivity $3.19 \mathrm{dS} . \mathrm{m}^{-1}$, and (6) a pH 7.9. The total dissolved solids and $\mathrm{pH}$ of the irrigation water applied to the plants were $788 \mathrm{mg} \cdot \mathrm{L}^{-1}$ and 7.8 , respectively.

\subsection{Experimental Design}

There were three main factors that were considered in this study: (1) the tree age of date palm cv. "Barhee": six and thirteen-year-old fruit-bearing palms were included; (2) the source of the date palm offshoots of cv. "Barhee": six and thirteen-year-old fruit-bearing palms that were either detached from a field-growing mother plant (conventional offshoots, $\mathrm{CO}$ ) or that were derived through non-conventional techniques (tissue culture offshoots, TC) were selected; (3) pollination interventions: two types of pollination interventions were used. The first pollination intervention took place in spathes that had opened naturally (naturally opened pollination, NOP), and the other was completed by manually opening the spathes (forced opened pollination, FOP) after full maturity symptoms appeared (cracking noise of the spathe on hand pressing). An equal number of male pollen strands from the same species were placed between the female strands of each group. The experiment layout was a randomized complete block design with six replicates in each treatment. The total number of uniform trees included in the study were forty-eight palms altogether, which were divided equally into $\mathrm{CO}$ and TC types.

\subsection{Pollination Practice}

In order to obtain strands for pollination, 12-year-old male spathes were taken from the orchard. With the use of a sharp knife, the protective coverings of male spathes were removed and were placed on a brown paper sheet. Male flower strands were removed individually, and nine equal-sized strands were placed in each female spathe. The pollination method adopted in this study was the strand placement method, which was conducted at $11 \mathrm{am}$, which was when the orchard temperature was above $25^{\circ} \mathrm{C}$, which is a temperature that is favorable for floral fertilization. To prevent contamination, all the pollinated spathes were covered with paper bags, which were removed once the fruit set. Each fruit cluster was covered with polyethylene mesh bags during the mid-summer period to protect it from birds and insects. All cultural practices such as leaf pruning, irrigation, and nutrient fertilization were carried out accordingly.

\subsection{Abnormal Fruit Set}

The fruit set failure symptoms were measured by examining four spathes located at each side of the date palm tree four weeks after pollination. The abnormality of the fruit set was calculated using the percentage rate index, as shown in Table 1. 
Table 1. Rating index of fruit set failure.

\begin{tabular}{cc}
\hline Index & Description (\%) \\
\hline 1 & $\leq 25 \%$ abnormal fruit set \\
2 & $25-50 \%$ abnormal fruit set \\
3 & $50-75 \%$ abnormal fruit set \\
4 & Above $75 \%$ abnormal fruit set \\
\hline
\end{tabular}

\subsection{Analysis of Hormones}

Random samples of female date flowers and fruit at different maturity stages were collected on the first day of pollination (0 days) followed by collection on 3, 7, 14, 21, 28, $35,42,49,56,63$, and 84 days after pollination (DAP). The samples were immediately frozen with liquid nitrogen and were placed in dry ice until they were transported to the laboratory. The samples were stored at temperatures under $-20^{\circ} \mathrm{C}$ until the laboratory analysis could take place.

\subsubsection{Standard Stock Solutions Preparation}

One milligram of each plant hormone (ABA, $\mathrm{GA}_{3}$, and IAA) was dissolved separately in one millilitre of methanol (50 percent) and was stored at $-20{ }^{\circ} \mathrm{C}$ to prepare their standard stock solutions. Daily, aliquots of these standard stock solutions were diluted with 50 percent methanol, and the working solution was prepared.

\subsubsection{Sample Extraction}

Plant hormones (IAA, $\mathrm{GA}_{3}$, and $\mathrm{ABA}$ ) were extracted from fruit specimens using the method of Dobrev et al. [61] with some alterations. A high-speed homogenizer was used to homogenise the sliced date fruit samples. The homogenised plant samples $(5 \mathrm{~g})$ were placed in a $50 \mathrm{~mL}$ centrifuge tube and were extracted twice with $40 \mathrm{~mL}$ of the extractants followed by ultrasonic mixing for $15 \mathrm{~min}$ after each extraction. An amount of 5 grams of the homogenised date fruit samples were placed in a $50 \mathrm{~mL}$ centrifuge tube and were extracted twice with $40 \mathrm{~mL}$ of extractants followed by $15 \mathrm{~min}$ of ultrasonic mixing. The supernatant was mixed after centrifugation at $2000 \mathrm{rpm}$ for $20 \mathrm{~min}$. For further analysis, the mixed extracts were evaporated and were diluted to $5 \mathrm{~mL}$ using methanol/water/formic acid $(10 / 95 / 0.1, v / v / v)$.

\subsubsection{Sample Purification}

The supernatants were purified using C18 HPLC cartridges after they had been diluted in $5 \mathrm{~mL}$ of the aforementioned solution containing a concentration of methanol/water/formic acid. An amount of $6 \mathrm{~mL}$ of methanol was used to activate and condition the cartridges, and $3 \mathrm{~mL}$ methanol/water/formic acid (10/95/0.1, v/v/v) was used to equilibrate them. Each fruit sample was placed onto a cartridge and was rinsed with $3 \mathrm{~mL}$ of methanol/water/formic acid. The plant phytohormones were eluted with $2 \times 3 \mathrm{~mL}$ of the methanol/water/formic acid solution. Before HPLC analysis, the acquired eluates were dried using nitrogen evaporators, diluted in $1 \mathrm{~mL}$ of $80 \%$ methanol, and filtered by a $0.45 \mu \mathrm{m}$ microfiltration membrane.

\subsubsection{High-Performance Liquid Chromatography (HPLC) Analysis}

PerkinElmer ${ }^{\circledR}$ HPLC system (Flexar LC, PerkinElmer Inc, Waltham, MA 02451, USA) with a Flexar PDA LC detector was used to sense specific plant hormones. The HPLC variables were managed by the Waters Empower 3 software (Waters Corporation, Waltham, MA 02451, USA), which also processed the data. A reversed-phase $2.7 \mu \mathrm{m}$ HPLC column RP C18 $\left(15 \mathrm{~cm} \times 2.1 \mathrm{~mm}\right.$, Ascentis ${ }^{\circledR}$ Express, Merck, KGaA, Darmstadt, Germany) was used for separation. In a linear gradient, eluent $A$ (water/acetic acid $=99.9 \% / 0.1$ ) and eluent B (methanol) were blended as follows: 20-70\% eluent B for the first 0-40 $\mathrm{min}$; 70-95\% eluent $B$ for the next $40-50 \mathrm{~min}$; and $95 \%$ eluent $B$ for the last 50-54 min. The column heater 
was adjusted at $30^{\circ} \mathrm{C}$, and the flow rate was $0.9 \mathrm{~mL} \cdot \mathrm{min}^{-1}$. The PDA absorption spectra of the compounds were measured between 210 and $500 \mathrm{~nm}$ [62].

\subsection{Statistical Analysis}

The hormonal pattern data for the two types of palm trees (CO and TC) that were 6-13 years of age were evaluated using SPSS version 23 software (SPSS Inc., Chicago, IL, USA) for the NOP and FOP pollination interventions at different time intervals after pollination. At a probability of $<0.05$, Tukey's test was employed to determine the least significant difference between the experimental means.

\section{Results}

Figure $2 \mathrm{~A}-\mathrm{F}$ showed a comparison between the mean values of the IAA, $\mathrm{GA}_{3}$, and ABA content under NOP and FOP types at different times (0 to 84 DAP) for 6-year-old $\mathrm{CO}$ and TC date palm trees. The results indicated that the hormones IAA and $\mathrm{GA}_{3}$ were significantly higher in the fruits of $\mathrm{CO}$ date palms than they were in the TC ones. In contrast, the hormone of $\mathrm{ABA}$ was lower in the fruits of the $\mathrm{CO}$ date palms than it was in the TC date palms under the two pollination types (NOP and FOP). In the fruits of the 6-year-old CO plants (Figure 2A), the regulation of IAA was non-significant on the day of pollination (0 DAP) in the NOP $\left(89.70 \cdot \mu \mathrm{g} \cdot \mathrm{kg}^{-1} \mathrm{FW}\right)$ and FOP $\left(85.00 \mu \mathrm{g} \cdot \mathrm{kg}^{-1} \mathrm{FW}\right)$ groups, which increased curvilinearly up to $35 \mathrm{DAP}$ in the NOP trees $\left(257.13 \mu \mathrm{g} \cdot \mathrm{kg}^{-1} \mathrm{FW}\right)$ and at $28 \mathrm{DAP}$ in the FOP trees $\left(178.58 \mu \mathrm{g} \cdot \mathrm{kg}^{-1} \mathrm{FW}\right)$. However, after $49 \mathrm{DAP}$ in NOP and NOP, the IAA concentration decreased. Similarly, in the fruits of the TC plants (Figure 2B), the IAA concentration was $65.70 \mu \mathrm{g} \cdot \mathrm{kg}^{-1} \mathrm{FW}$ after the first DAP in the NOP plants and $62.78 \mu \mathrm{g} \cdot \mathrm{kg}^{-1} \mathrm{FW}$ in the FOP plants, showing an increase to $78.38 \mu \mathrm{g} \cdot \mathrm{kg}^{-1} \mathrm{FW}$ in the NOP plants at 49 DAP and $68.62 \mu \mathrm{g} \cdot \mathrm{kg}^{-1} \mathrm{FW}$ in the FOP plants at 63 DAP. Similarly, the $\mathrm{GA}_{3}$ concentration was significantly different in the fruits of the $\mathrm{CO}$ plants (Figure $2 \mathrm{C}$ ) on the day of pollination in the NOP $\left(307.03 \mu \mathrm{g} \cdot \mathrm{kg}^{-1} \mathrm{FW}\right)$ and FOP $\left(253.20 \mu \mathrm{g} \cdot \mathrm{kg}^{-1} \mathrm{FW}\right)$ plants, which increased linearly up to 84 DAP in the NOP $\left(421.40 \mu \mathrm{g} \cdot \mathrm{kg}^{-1} \mathrm{FW}\right)$ and FOP $\left(351.82 \mu \mathrm{g} \cdot \mathrm{kg}^{-1} \mathrm{FW}\right)$ plants. A similar trend was observed in the fruits of the TC plants (Figure 2D), where a NOP had $110.53 \mu \mathrm{g} \cdot \mathrm{kg}^{-1} \mathrm{FW}$ concentration, and FOP had $91.15 \mu \mathrm{g} \cdot \mathrm{kg}^{-1} \mathrm{FW} \mathrm{GA} 3$ concentration on the day of pollination. The level of $\mathrm{GA}_{3}$ increased linearly until 84 DAP, i.e., $123.57 \mu \mathrm{g} \cdot \mathrm{kg}^{-1} \mathrm{FW}$ and $111.72 \mu \mathrm{g} \cdot \mathrm{kg}^{-1} \mathrm{FW}$ in NOP and FOP, respectively. The concentration of $\mathrm{ABA}$ was higher in the fruits of the CO plants (Figure 2E) on 7 DAP in the NOP $\left(19.13 \mu \mathrm{g} \cdot \mathrm{kg}^{-1} \mathrm{FW}\right)$ and FOP $\left(12.40 \mu \mathrm{g} \cdot \mathrm{kg}^{-1} \mathrm{FW}\right)$ groups, which significantly decreased afterward up until 84 DAP. An ABA showed an antagonistic trend in the fruits of the TC plants (Figure 2F), where ABA significantly increased on the day of pollination (22.85 $\mu \mathrm{g} \cdot \mathrm{kg}^{-1} \mathrm{FW}$ in NOP and $20.18 \mu \mathrm{g} \cdot \mathrm{kg}^{-1} \mathrm{FW}$ in FOP) until 84 DAP (44.88 $\mu \mathrm{g} \cdot \mathrm{kg}^{-1} \mathrm{FW}$ in NOP and $39.35 \mu \mathrm{g} \cdot \mathrm{kg}^{-1} \mathrm{FW}$ in FOP).

The IAA, $\mathrm{GA}_{3}$, and $\mathrm{ABA}$ data were recorded at different time intervals (0 to $\left.84 \mathrm{DAO}\right)$, as shown in Figure 3A-F, and are related to the 13-year-old date palm trees of the CO and TC trees pollinated by the NOP and FOP methods. Figure $3 \mathrm{~A}-\mathrm{F}$ shows that the hormones IAA and $\mathrm{GA}_{3}$ were significantly higher in $\mathrm{CO}$ date palm fruits than in the TC plants. However, the response of ABA was the opposite, as it was higher in the fruits of the TC plants than it was in the CO plants. Comparing NOP and FOP, IAA, GA, and $\mathrm{ABA}$ were higher in NOP. In the fruits of the 13-year-old CO plants (Figure $3 \mathrm{~A}$ ), the IAA concentration was significantly different between the NOP $\left(132.25 \mu \mathrm{g} \cdot \mathrm{kg}^{-1} \mathrm{FW}\right)$ and FOP $\left(111.27 \mu \mathrm{g} \cdot \mathrm{kg}^{-1} \mathrm{FW}\right)$ groups on the first DAP. It increased curvilinearly up to 42 DAP in NOP $\left(333.13 \mu \mathrm{g} \cdot \mathrm{kg}^{-1} \mathrm{FW}\right)$ and up to 35 DAP in FOP $\left(248.90 \mu \mathrm{g} \cdot \mathrm{kg}^{-1} \mathrm{FW}\right)$; afterward, it decreased. Similarly, in the fruits of the TC plants (Figure 3B), the IAA concentration was at its minimum on the day of pollination, i.e., $112.00 \mu \mathrm{g} \cdot \mathrm{kg}^{-1} \mathrm{FW}$ (NOP) and $97.52 \mu \mathrm{g} \cdot \mathrm{kg}^{-1} \mathrm{FW}$ (FOP), which increased to $361.10 \mu \mathrm{g} \cdot \mathrm{kg}^{-1} \mathrm{FW}$ in NOP and $360.93 \mu \mathrm{g} \cdot \mathrm{kg}^{-1} \mathrm{FW}$ in FOP on 49 DAP. The $\mathrm{GA}_{3}$ concentration was significantly different in the fruits of the $\mathrm{CO}$ plants (Figure $3 \mathrm{C}$ ) on the day of pollination in NOP $\left(350.90 \mu \mathrm{g} \cdot \mathrm{kg}^{-1} \mathrm{FW}\right)$ and FOP $\left(302.22 \mu \mathrm{g} \cdot \mathrm{kg}^{-1} \mathrm{FW}\right)$, which increased linearly up to 42 DAP 
in NOP $\left(421.75 \mu \mathrm{g} \cdot \mathrm{kg}^{-1} \mathrm{FW}\right)$ and FOP $\left(348.3882 \mu \mathrm{g} \cdot \mathrm{kg}^{-1} \mathrm{FW}\right)$. Afterward, there was no significant difference in $\mathrm{GA}_{3}$ concentration until the last time interval (84 DAP). A similar trend was noted in the fruits of the TC plants (Figure 3D), where NOP had $281.20 \mu \mathrm{g} \cdot \mathrm{kg}^{-1} \mathrm{FW}$, and FOP had $223.07 \mu \mathrm{g} \cdot \mathrm{kg}^{-1} \mathrm{FW} \mathrm{GA}$ concentration on the day of pollination, which increased linearly up to $391.53 \mu \mathrm{g} \cdot \mathrm{kg}^{-1} \mathrm{FW}$ (NOP) and $310.60 \mu \mathrm{g} \cdot \mathrm{kg}^{-1} \mathrm{FW}$ (FOP) on 49 and $42 \mathrm{DAP}$, respectively. Contrary to IAA and $\mathrm{GA}_{3}$ response at different time intervals, the $\mathrm{ABA}$ concentration decreased with the increased time intervals (from 0 to $84 \mathrm{DAP}$ ). The ABA was higher in the fruits of the CO plants (Figure 3E) on 3 DAP in NOP $\left(19.67 \mu \mathrm{g} \cdot \mathrm{kg}^{-1} \mathrm{FW}\right)$ and on the day of pollination in FOP $\left(15.72 \mu \mathrm{g} \cdot \mathrm{kg}^{-1} \mathrm{FW}\right)$, which significantly decreased afterward until 28 DAP in NOP $\left(12.37 \mu \mathrm{g} \cdot \mathrm{kg}^{-1} \mathrm{FW}\right)$ and 21 DAP in FOP $\left(10.87 \mu \mathrm{g} \cdot \mathrm{kg}^{-1} \mathrm{FW}\right)$. There was a non-significant difference in the ABA concentration after these time intervals in both the NOP and FOP groups. A similar ABA trend was observed in the fruits of the TC plants (Figure 3F), where ABA significantly increased on the day of pollination in NOP $\left(23.00 \mu \mathrm{g} \cdot \mathrm{kg}^{-1} \mathrm{FW}\right)$ and on 3 DAP in FOP $\left(14.15 \mu \mathrm{g} \cdot \mathrm{kg}^{-1} \mathrm{FW}\right)$. It decreased afterward until 42 DAP in NOP $\left(11.73 \mu \mathrm{g} \cdot \mathrm{kg}^{-1} \mathrm{FW}\right)$ and 21 DAP in FOP $\left(11.37 \mu \mathrm{g} \cdot \mathrm{kg}^{-1} \mathrm{FW}\right)$. There was no significant difference among ABA concentrations after these time intervals in both the NOP and FOP groups.

The concentration of IAA (ANOVA, F5, $10=1538, p<0.001$ ), GA 3 (ANOVA, F5, $10=177, p<0.001$ ), and ABA (ANOVA, F5, $10=4.76, p<0.001$ ) significantly varied with the DAP. A similar significant difference between the mean values of IAA, $\mathrm{GA}_{3}$, and ABA concentrations at different DAP ( 0 to 84 days) was also observed. The difference between $\mathrm{TC}$ and $\mathrm{CO}$ date palm plants was significant regarding the concentrations of IAA (ANOVA, F5, $1=7508, p<0.001$ ), GA 3 (ANOVA, F5, $1=12618, p<0.001$ ), and ABA (ANOVA, F5, $1=7412, p<0.001$ ). Similarly, the difference between the age of the date palm plants (6-year-old and 13-year-old) was also significant in regard to the concentrations of IAA (ANOVA, F5, $1=17186, p<0.001$ ), GA 3 (ANOVA, F5, $1=9405, p<0.001$ ), and ABA (ANOVA, F5, $1=1608, p<0.001$ ). The difference between the pollination types (NOP and FOP) was also significant regarding the concentration of IAA (ANOVA, F5, $1=4212$, $p<0.001$ ), $\mathrm{GA}_{3}$ (ANOVA, F5, $1=1581, p<0.001$ ), and ABA (ANOVA, F5, $1=196, p<0.001$ ).

The data presented in Table 2 indicate a significant variation between time intervals and hormones (IAA, $\mathrm{GA}_{3}$, and $\mathrm{ABA}$ ). The IAA concentration increased with the increase in time intervals. On the day of pollination, the IAA concentration was $94.52 \mu \mathrm{g} \cdot \mathrm{kg}^{-1} \mathrm{FW}$, which increased linearly until 49 DAP $\left(221.22 \mu \mathrm{g} \cdot \mathrm{kg}^{-1} \mathrm{FW}\right)$. The IAA concentration declined from 63 DAP onward. Similarly, the $\mathrm{GA}_{3}$ concentration was at its minimum on the day of pollination $\left(239.91 \mu \mathrm{g} \cdot \mathrm{kg}^{-1} \mathrm{FW}\right)$ and 3 DAP $\left(245.24 \mu \mathrm{g} \cdot \mathrm{kg}^{-1} \mathrm{FW}\right)$, as both were at par and were significantly increased until $84 \mathrm{DAP}\left(318.26 \mu \mathrm{g} \cdot \mathrm{kg}^{-1} \mathrm{FW}\right)$. A similar trend was observed in the ABA concentration, where a minimum value of $15.68 \mu \mathrm{g} \cdot \mathrm{kg}^{-1} \mathrm{FW}$ was estimated on the day when the samples were pollinated, and it increased by up to $18.65 \mu \mathrm{g} \cdot \mathrm{kg}^{-1} \mathrm{FW}$ on 84 DAP.

Table 3 shows the values of the rating index of the abnormal fruit set in the TC and $\mathrm{CO}$ of 6-and 13-year-old date palm trees. A statistically significant difference was observed comparing different ages (6- and 13-years-old), source (CO and TC), and pollination types (NOP and FOP). The abnormal fruit set was minimum in 13-year-old date palm trees irrespective of palm source (CO and TC) and pollination type (NOP and FOP). However, 6 -year-old TC plants, irrespective of pollination types (NOP and FOP), had a maximum rating index. The 6-year-old CO plants from the NOP group were statistically on par with 13-year-old TC and CO plants, irrespective of pollen types (NOP and FOP). In general, the 6-year-old TC date palm plants produced a higher number of abnormal fruits, the number of abnormal fruits was lowered in the 13-year-old CO and TC plants. 

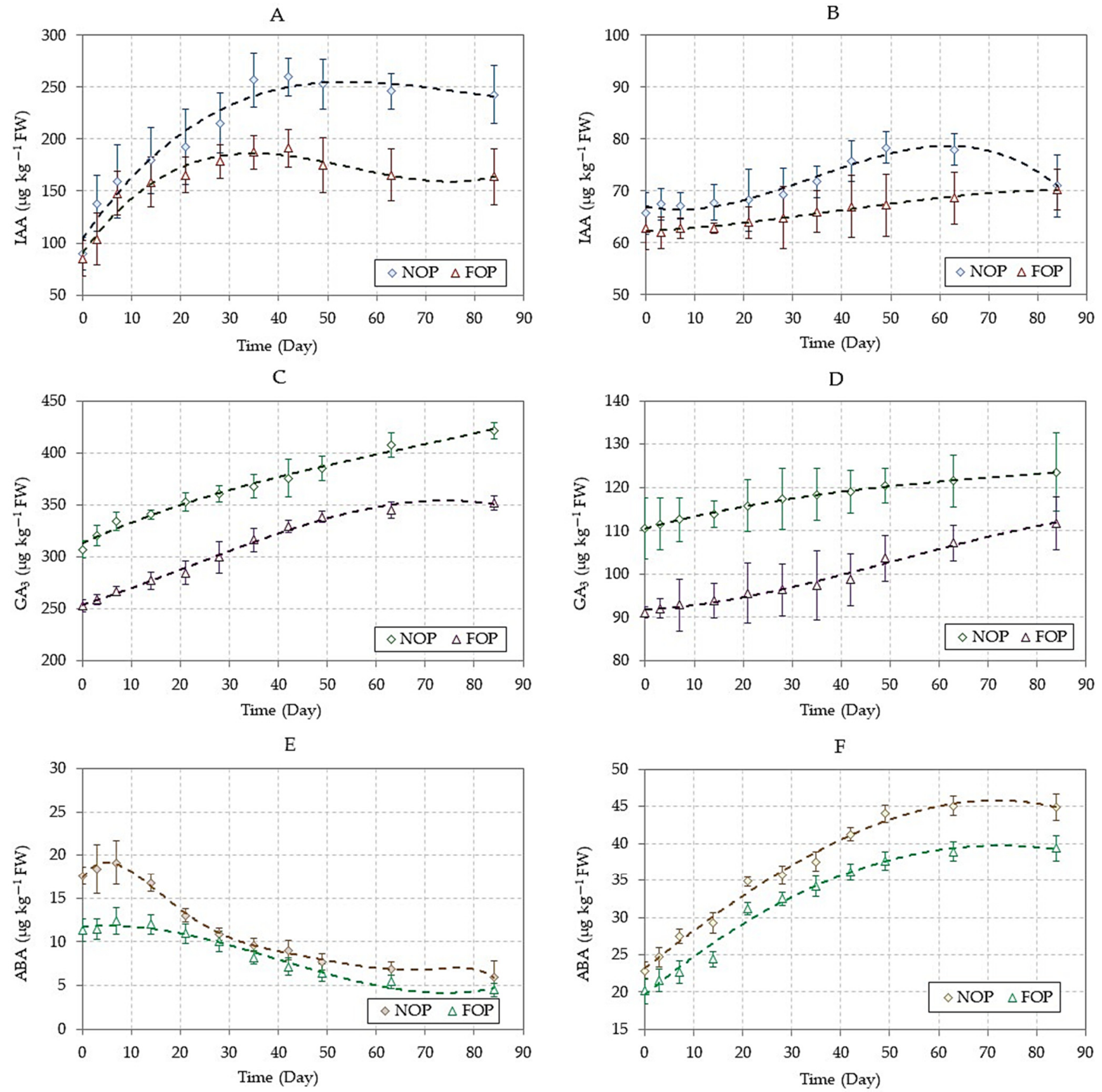

Figure 2. The data represent mean values \pm SD of IAA content under normal pollination type (A) and forced pollination type (B) $($ LSD0.05 = 16.514), GA3 content under normal pollination type (C) and forced pollination type (D) $($ LSD0.05 = 19.292), and ABA content under normal pollination type (E) and forced pollination type (F) (LSD0.05 = 1.891) at different times from 0 to 84 days after pollination for tissue culture and offshoot-derived date palms of 6-year-old palm trees. 
A

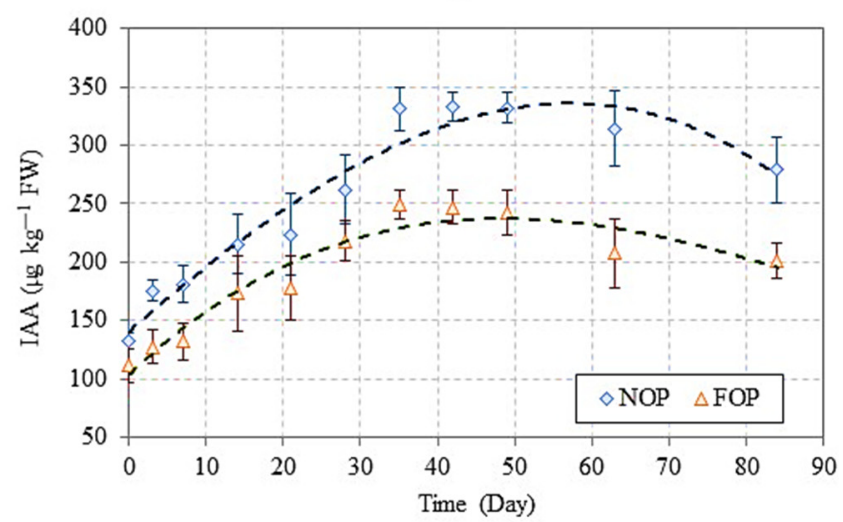

C

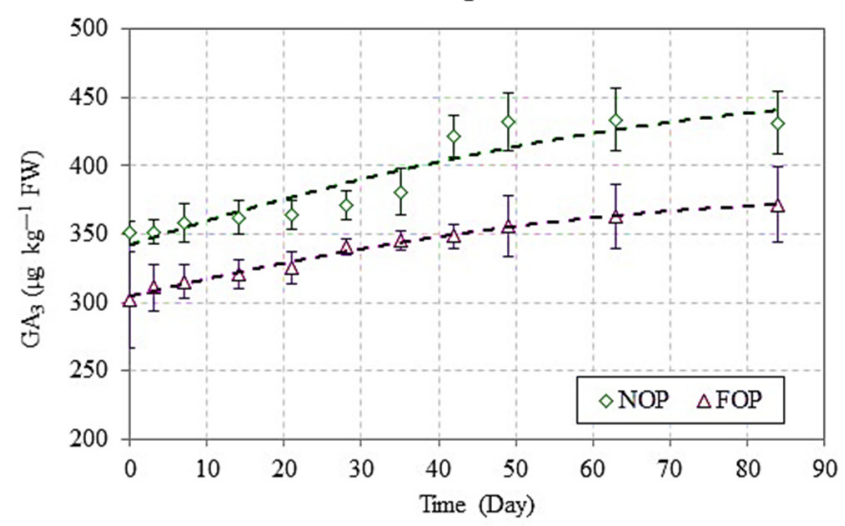

E

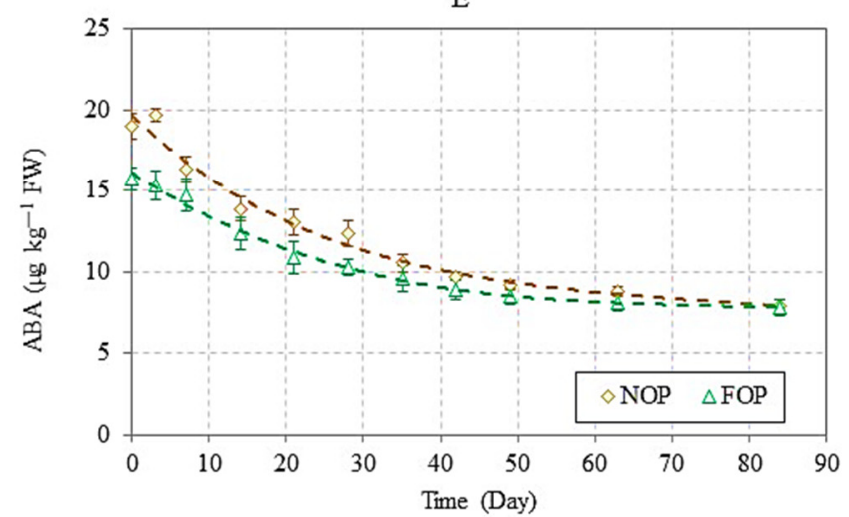

B

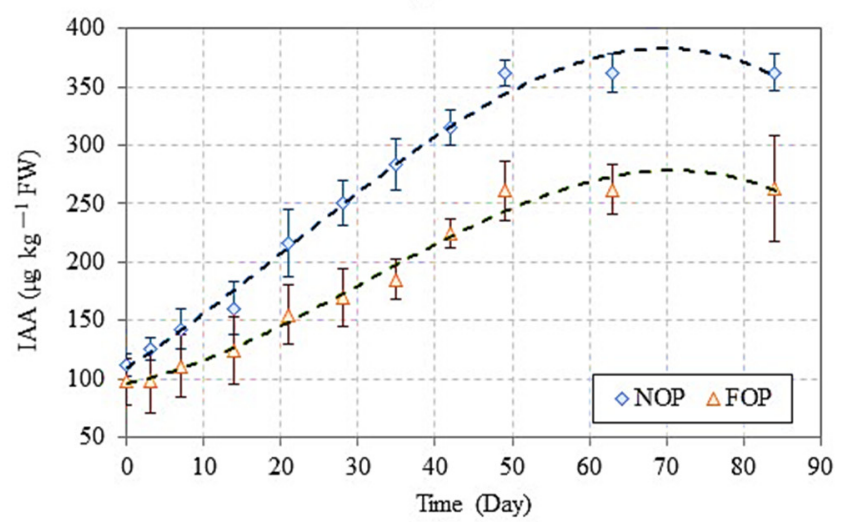

D

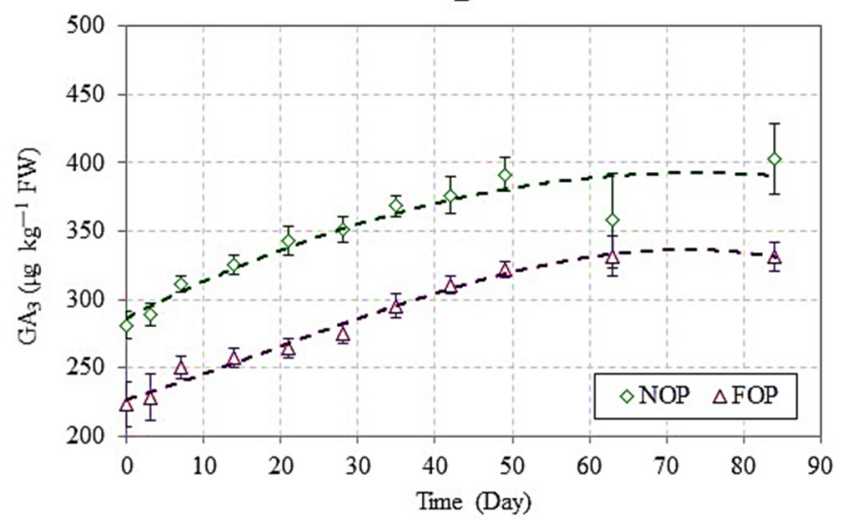

F

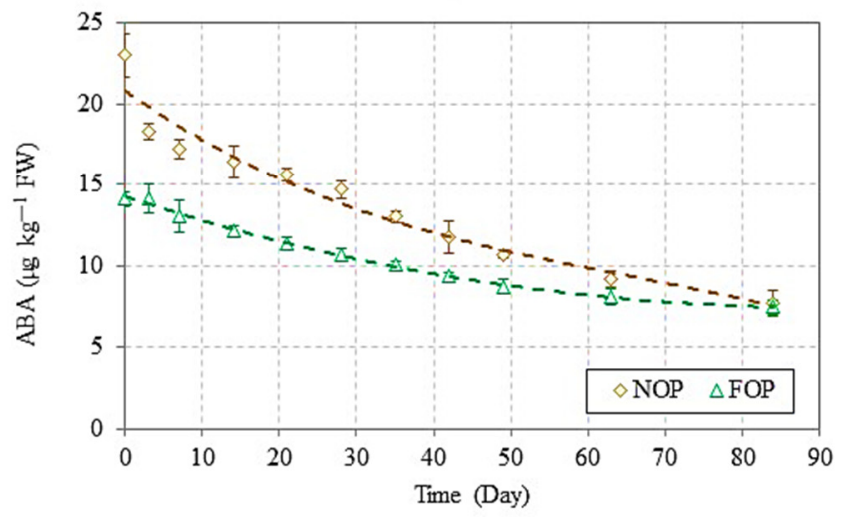

Figure 3. The data represent mean values \pm SD of IAA content under normal pollination type (A) and forced pollination type (B) $(\mathrm{LSD} 0.05=18.084), \mathrm{GA}_{3}$ content under normal pollination type $(\mathrm{C})$ and forced pollination type $(\mathrm{D})\left(\mathrm{LSD}_{0} \cdot 05=24.162\right)$, and ABA content under normal pollination type $(\mathbf{E})$ and forced pollination type $(\mathbf{F})\left(\mathrm{LSD}_{0.05}=4.284\right)$ at different times from 0 to 84 days after pollination for tissue culture and offshoot-derived date palms of 13-year-old palm trees.

Table 2. Mean values of indole acetic acid (IAA), gibberellin $\left(\mathrm{GA}_{3}\right)$, and abscisic acid (ABA) contents at different time intervals (from 0 to 84 days after pollination).

\begin{tabular}{cccc}
\hline \multirow{2}{*}{$\begin{array}{c}\text { Time Intervals } \\
\text { (DAP) }\end{array}$} & HAA & $\mathbf{G A}_{\mathbf{3}}$ & Aormones $\left(\boldsymbol{\mu g} \cdot \mathbf{k g}^{-\mathbf{1}} \mathbf{F W}\right)$ \\
\cline { 2 - 4 } & $94.52^{\mathrm{I}}$ & $239.91^{\mathrm{H}}$ \\
\hline 0 & $112.27^{\mathrm{H}}$ & $245.24^{\mathrm{H}}$ & $15.68^{\mathrm{C}}$ \\
3 & $125.35^{\mathrm{G}}$ & $255.17^{\mathrm{G}}$ & $16.29^{\mathrm{BC}}$ \\
7 & & $16.59^{\mathrm{BC}}$ \\
\hline
\end{tabular}


Table 2. Cont.

\begin{tabular}{cccc}
\hline \multirow{2}{*}{$\begin{array}{c}\text { Time Intervals } \\
\text { (DAP) }\end{array}$} & \multicolumn{3}{c}{ Hormones $\left(\boldsymbol{\mu g} \cdot \mathbf{k g}^{-\mathbf{1}} \mathbf{F W}\right)$} \\
\cline { 2 - 4 } & IAA & $\mathbf{G A}_{\mathbf{3}}$ & $\mathbf{A B A}$ \\
\hline 14 & $142.83^{\mathrm{F}}$ & $261.3^{\mathrm{FG}}$ & $16.60^{\mathrm{BC}}$ \\
21 & $157.99^{\mathrm{E}}$ & $268.2^{\mathrm{EF}}$ & $16.65^{\mathrm{BC}}$ \\
28 & $178.52^{\mathrm{D}}$ & $276.48^{\mathrm{E}}$ & $17.13^{\mathrm{A}-\mathrm{C}}$ \\
35 & $203.92^{\mathrm{C}}$ & $286.13^{\mathrm{D}}$ & $17.14^{\mathrm{A}-\mathrm{C}}$ \\
42 & $214.17^{\mathrm{B}}$ & $297.46^{\mathrm{C}}$ & $17.60^{\mathrm{AB}}$ \\
49 & $221.22^{\mathrm{A}}$ & $306.2^{\mathrm{BC}}$ & $17.86^{\mathrm{AB}}$ \\
63 & $212.3^{\mathrm{B}}$ & $308.47^{\mathrm{B}}$ & $17.94^{\mathrm{AB}}$ \\
84 & $206.62^{\mathrm{C}}$ & $318.26^{\mathrm{A}}$ & $18.65^{\mathrm{A}}$ \\
\hline
\end{tabular}

The same letter(s) in each column of the different hormones (IAA, $\mathrm{GA}_{3}$, and $\mathrm{ABA}$ ) indicate non-significant differences at the 0.05 level of probability (Tukey-Kramer test).

Table 3. Rate of abnormal fruit setting in tissue culture and offshoot-derived date palms of cv. Barhee.

\begin{tabular}{cccc}
\hline Age of Date Palm & Source of Date Palm & Pollination Type & Rating Index \\
\hline \multirow{3}{*}{ 6-year-old } & Tissue culture & NOP & $3.83^{\mathrm{A}}$ \\
& Conventional & FOP & $3.66^{\mathrm{B}}$ \\
\cline { 2 - 4 } & Offshoots & NOP & $1.33^{\mathrm{D}}$ \\
& Tissue culture & FOP & $1.51^{\mathrm{C}}$ \\
\hline \multirow{3}{*}{ 13-year-old } & NOP & $1.11^{\mathrm{D}}$ \\
& Conventional & FOP & $1.11^{\mathrm{D}}$ \\
\cline { 2 - 4 } & Offshoots & NOP & $1.11^{\mathrm{D}}$ \\
& FOP & $1.11^{\mathrm{D}}$ \\
\hline
\end{tabular}

The same letter of ${ }^{\mathrm{A}, \mathrm{B}, \mathrm{C}}$ or ${ }^{\mathrm{D}}$ in each column of the rating index indicated non-significant differences at the 0.05 level of probability (Tukey-Kramer test). NOP is the normal open pollination, and FOP is the forced open pollination. The values of the rating index of fruit set failure: a value of 1 indicates $\leq 25 \%$ abnormal fruit set, 2 indicates $25-50 \%$ abnormal fruit set, 3 indicates $50-75 \%$ abnormal fruit set, and 4 indicates above $75 \%$ abnormal fruit set.

\section{Discussion}

It is generally known that coordinated hormonal activity plays a vital role in fruit production in numerous plant species [63-65]. The present study's findings imply that multiple hormones, including IAA, $\mathrm{GA}_{3}$ (growth regulators), and $\mathrm{ABA}$ (growth inhibitor), are involved in the development of date palm fruit. Our results showed that the IAA and $\mathrm{GA}_{3}$ were significantly higher in 6-year-old $\mathrm{CO}$ date palms compared to the TC ones (Figure 2) during a 12-week investigation. In general, these hormones in both aged date palm trees and under both pollination interventions (NOP and FOP) increased gradually up to 6 to 10 weeks after pollination. The ABA at the other end followed contrasting patterns between the two types of derived date palms (CO and TC). Its concentration dropped sharply one week after pollination in the CO date palms while gradually increasing the TC date palms up to 7 weeks after pollination. Comparing 6- and 13-year-old date palm trees (Figures 2 and 3), it was evident that hormones IAA and $\mathrm{GA}_{3}$ were higher in 13-year-old palms in both the $\mathrm{CO}$ and TC groups. These plants also had a decrease in the ABA concentration after pollination. The trend showed that the ABA has an active antagonistic association with IAA and $\mathrm{GA}_{3}$ in developing fruit [66-68]. The regulation of IAA and $\mathrm{GA}_{3}$ suppressed the active role of $\mathrm{ABA}$ to reduce fruit development. Therefore, a reduction of ABA can be observed in 6-year-old CO plants, 13-year-old CO plants, and TC plants where IAA and $\mathrm{GA}_{3}$ increased after pollination and fruit set. The response of $\mathrm{ABA}$ was the opposite in the 6-year-old TC plants, where it increased, and the IAA and $\mathrm{GA}_{3}$ concentrations were much lower than they were the same aged $\mathrm{CO}$ plants. Considering these interactions, they might be the reason for a higher rate of fruit abnormality in 6-year-old TC plants (Table 3). Hadi et al. [50] found that following pollination, parthenocarpic date palm fruits had higher levels of IAA and $\mathrm{GA}_{3}$ than normal fruits. However, the information on ABA 
concentration is missing from their study. The changes in IAA concentration during fruit development could indicate the significance of this natural hormone in controlling different stages of fruit growth. The high IAA concentration of the female flower of the cv. Hillawi date palm was observed to set parthenocarpic fruit if not pollinated. However, it dropped at fruit set stage, rose during rapid cell division, and declined as the fruit approached the ripening phase [69]. A similar IAA response was observed in the present study in both 6- and 13-year-old plants, irrespective of the plant source. We observed a decline in the IAA concentration at the end of the Bisr stage (84 DAP) when the ripening phase started.

In another study, IAA and $\mathrm{GA}_{3}$ gradually increased after pollination up to almost 16 weeks and then slowly dropped while ABA continued to increase up to 20 weeks after pollination [70]. With the exception of the sharp decline in $\mathrm{ABA}$, which could indicate a synergetic action involving IAA, $\mathrm{GA}_{3}$, and $\mathrm{ABA}$ to reduce the inhibitory effects of $\mathrm{ABA}$ and improve fruit growth and development, these trends are similar to our study. However, we noticed an increases in the ABA concentration up to 84 DAP in the 6-year-old TC plants, which had the highest rate of parthenocarpic fruits (Figure 2F). For unclear reasons, the interactions of endogenous hormones deter individual hormonal responses [70]. The hormonal patterns in the 13-year-old CO and TC date palms followed almost followed trends that were almost identical to those of the younger date palms (6-year-old), with the exception of the ABA, which gradually decreased for both date palm types (CO and TC) after pollination (Figure 3). In our study, IAA and $\mathrm{GA}_{3}$ levels demonstrated a gradual increase at the early stages of fruit growth and development. The levels of IAA and $\mathrm{GA}_{3}$ showed a gradual rise during the early stages of fruit growth and development. Several previous investigations found a link between early rapid cell division, cell expansion, and rapid fruit growth as well as the rise of both hormones [41,60,71]. In pea and tomato, auxin and gibberellin have a synergistic effect on fruit growth, implying that the two phytohormones work together to regulate fruit development [54,72]. The studies of AbdAlaal et al. [73] highlighted the crucial role of IAA and $\mathrm{GA}_{3}$ in date palm fruit growth and development by enhancing fruit growth with the exogenous application of both hormones to flowers of the cv. Khadrawi date palm. The gradual decrease of the hormone ABA at the early stages of fruit growth in the 13-year-old TC date palms reflected an exciting trend. The trend was quite the opposite to that of the 6-year-old TC plants under both pollination interventions. The changes in the regulation of the hormonal levels probably reflect physiological and metabolic changes within the date palm tree that were induced by environment and tree age. These changes most likely contributed to enhancing the fruit sets and reduced abnormal fruiting. Other authors have emphasized the interactive effects of $\mathrm{ABA}$ with IAA and $\mathrm{GA}_{3}$ in promoting fruit growth and development $[34,55,66,68,74]$. Structurally, the gradual integration of the two sister carpels immediately after successful floral fertilization has been previously reported $r$ [75]. This phenomenon does not occur in abnormal fruits where all of the carpels become rudimentary at a particular stage of fruit growth, even with pollination. Considering this observation, it is likely that with successful floral fertilization and the integration of the two carpels that the ABA hormone played a minimal role in this fruit growth stage. Its abrupt decline assists in promoting successful early fruit growth and development.

In certain instances, even with successful pollination, none of the carpels progress into full fruit, resulting in parthenocarpic abnormal fruit $[3,27,28,75]$. After successful pollination, the regulation of this process is a complex procedure that involves several components, including environmental factors, hormones, and their active stimulus of signaling pathways [48,71]. Our data have shown that the abnormal fruit setting in 6-year-old TC and CO date palms was significantly higher in the TC palms under both pollination interventions (Table 3). Furthermore, the 6-year-old TC palms have also shown significantly higher abnormal fruit sets than the 13-year-old TC palms. However, no significant differences were observed between the 13-year-old TC and CO date palm trees, irrespective of the pollination interventions. Two key observations have emerged from these data. The first observation was the impressive improvement of fruit growth and development in 
the TC date palm trees when they reached 13 years of age. The other was the relatively low abnormal fruit set in young and old CO date palm trees. Our data show that the hormonal levels of ABA in young TC date palm trees consistently increased during the 63 DAP (Figure 2F). On the other hand, the ABA levels dropped sharply 7 DAP in the young $\mathrm{CO}$ date palms (Figure 2E). Furthermore, the ABA concentrations in 13-year-old TC and $\mathrm{CO}$ date palm trees decreased immediately after pollination interventions (Figure $3 \mathrm{E}, \mathrm{F}$ ). This response, in addition to the consistent increase in the levels of IAA and $\mathrm{GA}_{3}$ during the early days of fruit growth and development, may have likely created physiological and metabolic conditions that favor normal fruit sets. The high levels of ABA during early date fruit growth and development, on the other hand, may have led to the inhibition of the subsequent development events after pollination, resulting in an abnormal fruit set. In another study, sucrose concentrations were found to be critical in the regulation of ABA accumulation throughout strawberry fruit development and ripening [76]. The decreased ABA concentration in our study may have aided abnormal fruit production because date fruits usually have very low sugar content during early fruit development [77]. The consistent abundance of IAA and $\mathrm{GA}_{3}$ at the same period of development was demonstrated in many other studies $[42,56]$.

In our study, we observed that as the young TC date palm trees grew older, the inhibitory conditions that prevent abnormal fruit sets faded, and the date palm trees fruited normally. This phenomenon was also observed in many date palm cultivars. However, the degree of severity and duration of the abnormal fruit set significantly differed between cultivars $[28,30,78,79]$. The most probable factors attributed to this phenomenon were phenotypic and/or tissue residual effects that decrease as trees grow older [30].

\section{Conclusions}

It was evident that the hormonal levels and patterns guided by tree age and source play a vital role in normal fruit sets. The increasing levels of ABA during the early fruit growth phase of the 6-year-old TC date palms were likely to have intervened in a suppressive way in order to interfere in the actions of IAA and $\mathrm{GA}_{3}$ to promote fruit growth. In addition, this phenomenon seemed to fade as the 6-year-old TC date palms grow older. The situation may point to temporary inhibitory conditions that interact with the environment and other metabolic factors and that eventually diminish as the date palms grow older and reach their full commercial production capacity. The concentrations of IAA and $\mathrm{GA}_{3}$ was much higher in older date palm trees (13-year-old) in both pollination interventions (NOP and FOP) and sources of offshoots (CO and TC). However, it was significantly lower in 6-year-old trees irrespective to offshoot source. Our study has opened a pathway to further investigate this phenomenon through the exogeneous application of these hormones and whether exogenous application can overcome abnormal fruit formation in young TC plants.

Author Contributions: Conceptualization, H.A.-D., M.M. (Maged Mohammed), and M.M. (Muhammad Munir); methodology, H.A.-D., M.M. (Maged Mohammed), and M.M. (Muhammad Munir); software, M.M. (Maged Mohammed); validation, H.A.-D., M.M. (Maged Mohammed), and M.M. (Muhammad Munir); formal analysis, M.M. (Maged Mohammed); investigation, H.A.-D., M.M. (Maged Mohammed), and M.M. (Muhammad Munir); resources, H.A.-D.; data curation, H.A.-D.; writing-original draft preparation, H.A.-D., M.M. (Maged Mohammed), and M.M. (Muhammad Munir); writing—review and editing, H.A.-D., M.M. (Maged Mohammed), and M.M. (Muhammad Munir); visualization, M.M. (Maged Mohammed); project administration, H.A.-D.; funding acquisition, H.A.-D. All authors have read and agreed to the published version of the manuscript.

Funding: The authors appreciate the Deanship of Scientific Research, King Faisal University, and extend their appreciation to the Deputyship for Research \& Innovation, Ministry of Education in Saudi Arabia for funding this research work through project number IFT20184.

Institutional Review Board Statement: Not applicable.

Informed Consent Statement: Not applicable.

Data Availability Statement: Not applicable. 
Acknowledgments: The authors gratefully acknowledge the availability of the date palm farms and laboratories for this study, which were provided by the Date Palm Research Center of Excellence, King Faisal University, Saudi Arabia.

Conflicts of Interest: The authors declare no conflict of interest.

\section{References}

1. FAOSTAT Food and Agriculture Organization of the United Nations. 2019. Available online: http://faostat.fao.org/site (accessed on 18 September 2019).

2. Tengberg, M. Beginnings and early history of date palm garden cultivation in the Middle East. J. Arid Environ. 2012, 86, 139-147. [CrossRef]

3. Reuveni, O. Date In CRC Handbook of Fruit Set and Development; CRC Press: Boca Raton, FL, USA, 1986; pp. 119-144.

4. Zaid, A.; Arias-Jimenez, E.J. Date Palm Cultivation. In FAO Plant Production and Protection Paper; FAO: Rome, Italy, 2002; Volume 156, p. 292.

5. $\quad$ Okuda, S.; Tsutsui, H.; Shiina, K.; Sprunck, S.; Takeuchi, H.; Yui, R.; Kasahara, R.D.; Hamamura, Y.; Mizukami, A.; Susaki, D.; et al. Defensin-like polypeptide LUREs are pollen tube attractants secreted from synergid cells. Nature 2009, 458, 357-361. [CrossRef] [PubMed]

6. Higashiyama, T.; Takeuchi, H. The mechanism and key molecules involved in pollen tube guidance. Annu. Rev. Plant Biol. 2015, 66, 393-413. [CrossRef] [PubMed]

7. Jaskani, M.J.; Naqvi, S.A. Storage and Viability Assessment of Date Palm Pollen. In Date Palm Biotechnology Protocols Volume II; Springer, Humana Press: New York, NY, USA, 2017; pp. 3-13.

8. Mohammed, M.; Alhajhoj, M.R.; Ali-Dinar, H.M.; Munir, M. Impact of a novel water-saving subsurface irrigation system on water productivity, photosynthetic characteristics, yield, and fruit quality of date palm under arid conditions. Agronomy 2020, 10, 1265. [CrossRef]

9. Munir, M.; Alhajhoj, M.R.; Sallam, A.A.M.; Ghazzawy, H.S.; Al-Bahigan, A.M. Effects of indigenous and foreign pollinizers on the yield and fruit characteristics of date palm cultivar Khalas. Iraqi. J. Agric. Sci. 2020, 51, 356-365.

10. Munir, M.; Alhajhoj, M.R.; Sallam, A.A.M.; Ghazzawy, H.S.; Al-Bahigan, A.M. Fruit yield and quality response of date palm cultivar Khalas to female inflorescence receptivity varied by pollination days. Plant Arch. 2020, 20, 4007-4014.

11. Zaid, A.; de Wet, M.P.F.; Djerb, A.O. Date Palm Cultivation; Food and Agriculture Organization (FAO): Rome, Italy, 1999.

12. Al-Shahib, W.; Marshall, R.J. The fruit of the date palm: Its possible use as the best food for the future? Int. J. Food Sci. Nutr. 2003, 54, 247-259. [CrossRef]

13. Chao, C.C.T.; Krueger, R.R. The date palm (Phoenix dactylifera L.): Overview of biology, uses, and cultivation. HortScience 2007, 42, 1077-1082. [CrossRef]

14. Johnson, D.V. Introduction: Date Palm Biotechnology from Theory to Practice. In Date Palm Biotechnology; Springer: Dordrecht, The Netherlands, 2011; pp. 1-11.

15. Zaid, A.; de Wet, P.F. Pollination and bunch management. Chapter 8 In: Zaid A (ed) Date palm cultivation. FAO Plant Prod. Prot. 2002, 156, 145-175.

16. Munir, M.; Al-Hajhoj, M.R.; Ghazzawy, H.S.; Sallam, A.A.M.; Al-Bahigan, A.M.; Al-Muiweed, M.A. A comparative study of pollination methods effect on the changes in fruit yield and quality of date palm cultivar Khalas. Asian J. Agric. Biol. 2020, 8 , 147-157. [CrossRef]

17. Gupta, A.; Godara, R.K.; Sharma, V.K.; Panda, A.K. Artificial Pollination: A Tool for Improving Fruiting Traits in Date palm (Phoenix dactylifera L.). Chem. Sci. Rev. Lett. 2017, 6, 1312-1320.

18. Salomón-Torres, R.; Krueger, R.; García-Vázquez, J.P.; Villa-Angulo, R.; Villa-Angulo, C.; Ortiz-Uribe, N.; Sol-Uribe, J.A.; Samaniego-Sandoval, L. Date palm pollen: Features, production, extraction and pollination methods. Agronomy 2021, 11, 504. [CrossRef]

19. El Mardi, M.O.; Al Said, F.A.J.; Sakit, C.B.; Al Kharusi, L.M.; Al Rahbi, I.N.; Al Mahrazi, K. Effect of pollination method, fertilizer and mulch treatments on the physical and chemical characteristics of date palm (Phoenix dactylifera) Fruit I: Physical characteristics. In Proceedings of the Acta Horticulturae, Leuven, Belgium; 2007; Volume 736, pp. 317-328. [CrossRef]

20. Mazri, M.A.; Meziani, R. An improved method for micropropagation and regeneration of date palm (Phoenix dactylifera L.). J. Plant Biochem. Biotechnol. 2013, 22, 176-184. [CrossRef]

21. Mazri, M.A.; Meziani, R.; El Fadile, J.; Ezzinbi, A. Optimization of medium composition for in vitro shoot proliferation and growth of date palm cv. Mejhoul. 3 Biotech 2016, 6, 111. [CrossRef]

22. Pierik, R.L.M. In vitro culture of higher plants as a tool in the propagation of horticultural crops. In Proceedings of the International Symposium on Propagation of Ornamental Plants 226, Geisenheim, Germany, 23-27 August 1987; pp. 25-40.

23. Kaeppler, S.M.; Kaeppler, H.F.; Rhee, Y. Epigenetic aspects of somaclonal variation in plants. Plant Mol. Biol. 2000, 43, 179-188. [CrossRef]

24. Bouhouche, N.; Al-Mazroui, H.S.; Zaid, A. Fertilization failure and abnormal fruit set in tissue culture-derived date palm (Phoenix dactylifera L.). In Proceedings of the III International Date Palm Conference 736, Abu Dhabi, United Arab Emirates, 19-21 February 2006; pp. 225-232. 
25. Bairu, M.W.; Aremu, A.O.; Van Staden, J. Somaclonal variation in plants: Causes and detection methods. Plant Growth Regul. 2011, 63, 147-173. [CrossRef]

26. Azizi, P.; Hanafi, M.M.; Sahebi, M.; Harikrishna, J.A.; Taheri, S.; Yassoralipour, A.; Nasehi, A. Epigenetic changes and their relationship to somaclonal variation: A need to monitor the micropropagation of plantation crops. Funct. Plant Biol. 2020, 47, 508-523. [CrossRef]

27. Al-Wasel, A.S. Vegetative and fruiting comparison of tissue culture derived and conventionally propagated date palm (Phoenix dactylifera L.) cv. Barhi trees. Vitr. Biol. Cell. Dev. Biol 2000, 36, 1010.

28. Djerbi, M. Abnormal fruiting of the date palm derived from tissue culture. In Proceedings of the Date Palm Inter. Symposium, Windhock, Namibia, 22-25 February 2000; pp. 22-25.

29. Ruffoni, B.; Savona, M. Physiological and biochemical analysis of growth abnormalities associated with plant tissue culture. Hortic. Environ. Biotechnol. 2013, 54, 191-205. [CrossRef]

30. Abd-Elhaleem, S.A.M.; Abd El-Latif, F.M.; El-Badawy, H.E.M.; AbdAlla, B.M.; El-Gioushy, S.F. Study of failure of fertilization in date palm (Phoenix dactylifera L.) BARHI CV. Plant Arch. 2020, 20, 2363-2368.

31. Ghosh, A.; Igamberdiev, A.U.; Debnath, S.C. Tissue culture-induced DNA methylation in crop plants: A review. Mol. Biol. Rep. 2021, 48, 823-841. [CrossRef]

32. Papareddy, R.K.; Nodine, M.D. Plant Epigenetics: Propelling DNA Methylation Variation across the Cell Cycle. Curr. Biol. 2021, 31, R129-R131. [CrossRef] [PubMed]

33. Gorguet, B.; Van Heusden, A.W.; Lindhout, P. Parthenocarpic fruit development in tomato. Plant Biol. 2005, 7, 131-139. [CrossRef] [PubMed]

34. Serrani, J.C.; Sanjuán, R.; Ruiz-Rivero, O.; Fos, M.; García-Martínez, J.L. Gibberellin regulation of fruit set and growth in tomato. Plant Physiol. 2007, 145, 246-257. [CrossRef]

35. Obrucheva, N. V Hormonal regulation during plant fruit development. Ontogenez 2014, 45, 14-27. [CrossRef] [PubMed]

36. Talon, M.; Caruso, M.; Gmitter, F.G., Jr. The Genus Citrus; Woodhead Publishing: London, UK, 2020.

37. O'Neill, S.D.; Nadeau, J.A. Postpollination flower development. Hortic. Rev. 1997, 19, 1-58.

38. Pharis, R.P.; King, R.W. Gibberellins and reproductive development in seed plants. Annu. Rev. Plant Physiol. 1985, 36, 517-568. [CrossRef]

39. Klee, H.J.; Giovannoni, J.J. Genetics and control of tomato fruit ripening and quality attributes. Annu. Rev. Genet. 2011, 45, 41-59. [CrossRef]

40. Seymour, G.B.; Ostergaard, L.; Chapman, N.H.; Knapp, S.; Martin, C. Fruit development and ripening. Annu. Rev. Plant Biol. 2013, 64, 219-241. [CrossRef]

41. Nitsch, J.P. Hormonal factors in growth and development. Biochem. Fruits Prod. 1970, 2, 427-472.

42. Mariotti, L.; Picciarelli, P.; Lombardi, L.; Ceccarelli, N. Fruit-set and early fruit growth in tomato are associated with increases in indoleacetic acid, cytokinin, and bioactive gibberellin contents. J. Plant Growth Regul. 2011, 30, 405-415. [CrossRef]

43. Ozga, J.A.; Reinecke, D.M. Hormonal Interactions in Fruit Development. J. Plant Growth Regul. 2003, 22, 73-81. [CrossRef]

44. Davies, P.J. The plant hormones: Their nature, occurrence, and functions. In Plant Hormones: Biosynthesis, Signal Transduction, Action; Springer: Dordrecht, The Netherlands, 2010; pp. 1-15. ISBN 9781402026867. [CrossRef]

45. Kumar, R.; Khurana, A.; Sharma, A.K. Role of plant hormones and their interplay in development and ripening of fleshy fruits. $J$. Exp. Bot. 2014, 65, 4561-4575. [CrossRef] [PubMed]

46. Liu, K.; Kang, B.C.; Jiang, H.; Moore, S.L.; Li, H.; Watkins, C.B.; Setter, T.L.; Jahn, M.M. A GH3-like gene, CcGH3, isolated from Capsicum chinense L. fruit is regulated by auxin and ethylene. Plant Mol. Biol. 2005, 58, 447-464. [CrossRef] [PubMed]

47. Zhang, M.; Yuan, B.; Leng, P. The role of ABA in triggering ethylene biosynthesis and ripening of tomato fruit. J. Exp. Bot. 2009, 60, 1579-1588. [CrossRef]

48. De Jong, M.; Wolters-Arts, M.; Feron, R.; Mariani, C.; Vriezen, W.H. The Solanum lycopersicum auxin response factor 7 (SlARF7) regulates auxin signaling during tomato fruit set and development. Plant J. 2009, 57, 160-170. [CrossRef]

49. Cheruth, A.J.; Kurup, S.S.; Subramaniam, S. Variations in hormones and antioxidant status in relation to flowering in early, mid, and late varieties of date palm (Phoenix dactylifera L.) of United Arab Emirates. Sci. World J. 2015, 2015, 846104. [CrossRef] [PubMed]

50. Hadi, S.; Al-Khalifah, N.S.; Moslem, M.A. Hormonal Basis of Shees' Fruit Abnormality in Tissue Culture Derived Plants of Date Palm. Int. J. Agric. Biol. 2015, 17, 607-612. [CrossRef]

51. De Jong, M.; Wolters-Arts, M.; Garc, J.L.; Mariani, C.; Vriezen, W.H. The Solanum lycopersicum auxin response factor 7 (SlARF7) mediates cross-talk between auxin and gibberellin signalling during tomato fruit set and development. J. Exp. Bot. 2011, 62, 617-626. [CrossRef]

52. Carrera, E.; Ruiz-Rivero, O.; Peres, L.E.P.; Atares, A.; Garcia-Martinez, J.L. Characterization of the procera tomato mutant shows novel functions of the SIDELLA protein in the control of flower morphology, cell division and expansion, and the auxin-signaling pathway during fruit-set and development. Plant Physiol. 2012, 160, 1581-1596. [CrossRef]

53. Ashour, N.E.; Mostafa, E.A.M.; Saleh, M.A.; Hafez, O.M. Effect of GA3, 6-benzylaminopurine and boric acid spraying on yield and fruit quality of barhee date palm. Middle East J. Agric. Res. 2018, 7, 278-286.

54. Serrani, J.C.; Ruiz-Rivero, O.; Fos, M.; García-Martínez, J.L. Auxin-induced fruit-set in tomato is mediated in part by gibberellins. Plant J. 2008, 56, 922-934. [CrossRef] 
55. Dorcey, E.; Urbez, C.; Blázquez, M.A.; Carbonell, J.; Perez-Amador, M.A. Fertilization-dependent auxin response in ovules triggers fruit development through the modulation of gibberellin metabolism in Arabidopsis. Plant J. 2009, 58, 318-332. [CrossRef]

56. Al-Kalifah, M.; Hadi, S.; Khan, F.A.; Khan, P.R.; Shanavaskhan, A.E.; Askari, E. Effect of plant growth regulators on fruit abnormality ('Shees') of tissue culture-derived date palm (Phoenix dactylifera L.). In Proceedings of the Proc. Fourth Symposium Date Palm Saudi Arabia, King Faisal University, Al-Hassa, Saudi Arabia, 5-8 May 2007; pp. 5-7.

57. Abbas, M.F.; Ibrahim, M.A. The role of ethylene in the regulation of fruit ripening in the Hillawi date palm (Phoenix dactylifera L). J. Sci. Food Agric. 1996, 72, 306-308. [CrossRef]

58. Serrano, M.; Pretel, M.T.; Botella, M.A.; Amoros, A. Physicochemical changes during date ripening related to ethylene production. Food Sci. Technol. Int. 2001, 7, 31-36. [CrossRef]

59. Chen, Y.; Grimplet, J.; David, K.; Castellarin, S.D.; Terol, J.; Wong, D.C.J.; Luo, Z.; Schaffer, R.; Celton, J.-M.; Talon, M.; et al. Ethylene receptors and related proteins in climacteric and non-climacteric fruits. Plant Sci. 2018, 276, 63-72. [CrossRef]

60. Attaha, A.H.M.; Al-Saadi, S.A.A.M. Anatomical and Hormonal Studies of Floral and Fruiting Behavior of Phoenix Dactylifera, cv. Barhee. Int. J. Curr. Adv. Res. 2015, 4, 531-536.

61. Dobrev, P.I.; Kam \inek, M. Fast and efficient separation of cytokinins from auxin and abscisic acid and their purification using mixed-mode solid-phase extraction. J. Chromatogr. A 2002, 950, 21-29. [CrossRef]

62. Zhu, S.; Chen, S.-W.; Li, Y. Simultaneous analysis of thirteen phytohormones in fruits and vegetables by SPE-HPLC-DAD. Food Sci. Biotechnol. 2020, 29, 1587-1595. [CrossRef] [PubMed]

63. Iqbal, N.; Khan, N.A.; Ferrante, A.; Trivellini, A.; Francini, A.; Khan, M.I.R. Ethylene role in plant growth, development and senescence: Interaction with other phytohormones. Front. Plant Sci. 2017, 8, 475. [CrossRef] [PubMed]

64. An, J.; Althiab Almasaud, R.; Bouzayen, M.; Zouine, M.; Chervin, C. Auxin and ethylene regulation of fruit set. Plant Sci. 2020, 292, 110381. [CrossRef]

65. Fenn, M.A.; Giovannoni, J.J. Phytohormones in fruit development and maturation. Plant J. 2021, 105, 446-458. [CrossRef] [PubMed]

66. Buta, J.G.; Spaulding, D.W. Changes in indole-3-acetic acid and abscisic acid levels during tomato (Lycopersicon esculentum Mill.) fruit development and ripening. J. Plant Growth Regul. 1994, 13, 163-166. [CrossRef]

67. Koshita, Y.; Takahara, T.; Ogata, T.; Goto, A. Involvement of endogenous plant hormones (IAA, ABA, GAs) in leaves and flower bud formation of satsuma mandarin (Citrus unshiu Marc.). Sci. Hortic. 1999, 79, 185-194. [CrossRef]

68. Setha, S.; Kondo, S.; Hirai, N.; Ohigashi, H. Xanthoxin, abscisic acid and its metabolite levels associated with apple fruit development. Plant Sci. 2004, 166, 493-499. [CrossRef]

69. Abbas, M.; Abdel Basit, O.; Abbas, M. Indole-3-acetic acid concentration during fruit development in date palm (Phoenix dactylifera I., cv. Hillawi). Fruits 2000, 55, 115-118.

70. Rastegar, S.; Rahemi, M.; Zargari, H. others Changes in endogenous hormones in fruit during growth and development of date palm fruits. Am.-Eurasian J. Agric. Environ. Sci. 2011, 11, 140-148.

71. Shabana, H.A.; Zaid, A.; Khalil, A.A. Date Palm Fruits Physiology, Harvesting and Handling; FAO: Rome, Italy, 2006.

72. Ozga, J.A.; Reinecke, D.M. Interaction of 4-chloroindole-3-acetic acid and gibberellins in early pea fruit development. Plant Growth Regul. 1999, 27, 33-38. [CrossRef]

73. Abd-Alaal, A.F.; Al-Salih, K.K.; Shabana, H.; Al-Salihy, G.J. Production of seedless dates by application of growth regulators. In Proceedings of the First International Symposium on the Date Palm, King Faisal University, Al-Hassa, Saudi Arabia, 22-25 March 1982; pp. 276-282.

74. Wang, H.; Schauer, N.; Usadel, B.; Frasse, P.; Zouine, M.; Hernould, M.; Latche, A.; Pech, J.-C.; Fernie, A.R.; Bouzayen, M. Regulatory features underlying pollination-dependent and-independent tomato fruit set revealed by transcript and primary metabolite profiling. Plant Cell 2009, 21, 1428-1452. [CrossRef]

75. Zaid, A.; De Wet, P.F. Chapter I Botanical and systematic description of date palm. In FAO Plant Prod. Prot. Pap; Food and Agriculture Organization (FAO): Rome, Italy, 1999; pp. 1-28.

76. Jia, H.; Wang, Y.; Sun, M.; Li, B.; Han, Y.; Zhao, Y.; Li, X.; Ding, N.; Li, C.; Ji, W. Sucrose functions as a signal involved in the regulation of strawberry fruit development and ripening. New Phytol. 2013, 198, 453-465. [CrossRef]

77. Amira, E.A.; Flamini, G.; Behija, S.E.; Manel, I.; Nesrine, Z.; Ali, F.; Mohamed, H.; Noureddine, H.A.; Lotfi, A. Chemical and aroma volatile compositions of date palm (Phoenix dactylifera L.) fruits at three maturation stages. Food Chem. 2011, 127, 1744-1754. [CrossRef]

78. McCubbin, M.J.; Zaid, A.; Van Stade, J. A southern African survey conducted for off-types on date palms produced using somatic embryogenesis. Emirates J. Food Agric. 2004, 16, 8-14. [CrossRef]

79. Cohen, Y.; Korchinsky, R.; Tripler, E. Flower abnormalities cause abnormal fruit setting in tissue culture-propagated date palm (Phoenix dactylifera L.). J. Hortic. Sci. Biotechnol. 2004, 79, 1007-1013. [CrossRef] 